UDC: 576.321 .36

\title{
The dynamics of actin filament polymerization in activated leukocytes under experimental diabetes mellitus against the background of agmatine administration
}

\author{
I. V. Brodyak, I. I. Bila, N. O. Sybirna \\ Ivan Franko National University of Lviv \\ 4, Hrushevskoho Str., Lviv, Ukraine, 79005 \\ iryna_brodyak@yahoo.com
}

\begin{abstract}
Aim. To research the impact of agmatine on the redistribution of actin fractions, which are represented by cytoskeletal actin filaments, short actin filaments of the plasma membrane skeleton and actin monomers (G-actin) in rat leukocytes under experimental diabetes mellitus (EDM). Methods. Leukocytes were lyzed in Triton X-100 and subjected to centrifugation to obtain cytoskeletal actin filaments, short actin filaments and actin monomers, which were separated in SDS-PAAG, followed by the immunoblot analysis of anti-actin antibodies. Results. Under EDM, an intensification of the process of short actin filament depolymerization and an increase in the G-actin content were observed in leukocytes activated by sialospecific wheat germ lectin (WGA). Against a background of agmatine administration, the response dynamics to the WGA-stimulating effect was characterized by an increase in actin polymerization in the fraction of cytoskeletal filaments already after 0.5 min exposure to lectin, an exceptionally rapid depolymerization process after $1 \mathrm{~min}$ of the lectin treatment, and return to the initial indices after 3 min exposure to lectin. Conclusions. In leukocytes of animals with EDM against a background of agmatine administration, the transduction of WGA-induced signal through sialoglycoconjugates causes the actin redistribution. It indicates that this polyamine helps to restore and maintain a functional response of leukocytes to the activation signals.
\end{abstract}

Keyword s: actin, leukocytes, agmatine, experimental diabetes mellitus.

\section{Introduction}

The experimental studies on leukocytes in the case of diabetes mellitus demonstrate significant violations of the morphofunctional state of the blood cells. The reduction of chemo- taxis capacity, phagocytic activity of leukocytes, the dysfunction of adhesion, aggregation and migration abilities of these cells correlate with the level of hyperglycemia of peripheral blood. In turn, the morphofunctional state of leukocytes is addicted to the complex interac-

(C) 2017 I. V. Brodyak et al.; Published by the Institute of Molecular Biology and Genetics, NAS of Ukraine on behalf of Biopolymers and Cell. This is an Open Access article distributed under the terms of the Creative Commons Attribution License (http://creativecommons.org/licenses/by/4.0/), which permits unrestricted reuse, distribution, and reproduction in any medium, provided the original work is properly cited 
tion among proteins of the membrane, the cytoskeleton and the network of intracellular signaling [1-3].

The actin cytoskeleton is a dynamic system involved in the adhesion and migration of leukocytes [4]. The process of leukocyte transfer from the peripheral blood into the subendotelium is triggered by the molecules of adhesion [5]. The formation of stable adhesion structures as a result of actin polymerization leads to the formation of actin comet tails, which are associated with integrins at the front end of leukocytes and induce $\beta 1$ integrin clustering, causing the formation an actin rafts on the cell surface in the area of lamelopodia and filopodia [6]. Lamelopodia contain a highly dense and extensive network of actin filaments, which are orientated from the sharp ends (positively charged) to the edge of the cell. The polymerization of actin generates the force that pushes the membrane forward, creating preconditions for new adhesion contacts of leukocytes with the endothelium involving filopodia [7]. Filopodia are made of densely staffed parallel filaments of actin (10 or more), the sharp ends of which are directed towards the membrane. The grouping of actin filaments is mediated by fascin, a binding protein. The polarized nature of actin filaments allows motor proteins to actively transport monomers of actin to the ends of filopodia, thus increasing the local actin polymerization [8]. The mechanism for increasing the level of polymerized actin (F-actin) involves an increase in the pool of actin monomers of globular actin (G-actin), which is required for the polymerization of new actin filaments, or may be caused by increased affinity of already existing filaments of F-actin to G-actin. Free negatively charged ends of actin filaments (where the lengthening of actin filaments occurs) are developed in several ways: by removing cap proteins, which in the attached position at growing ends of actin block the process of polymerization; by depolymerizing actin fragments owing to the disconnection of non-covalent bonds between actin monomers within actin filaments, which leads to the formation of shorter filaments with negatively charged free ends; by producing actin oligomers de novo [9].

The reorganization of the cytoskeleton occurs when $\mathrm{Ca}^{2+}$-dependent signaling cascades, involving Src family kinases and low-molecular GTFases, are activated [10]. GTFases of Rap1 family perform the activation of PI-3'kinase, which is required for the Rap1dependent activation of Rac (a member of small GTFase of the Rho family), through Vav2, and it is Rac that directly affects the organization of actin cytoskeleton [11]. PI-3'kinase enzyme plays a key role not only in the activation of adhesion molecules, but also in chemokine-induced cell adhesion and cell polarization [12]. In contrast, the relationship between L-selectins, CD44, CD43, ICAM1-3 and the cytoskeleton is performed through ezrin / radixin / moesin (ERM) protein family. Proteins of ERM family have both membrane and actin-binding domains, which enable their function as linkers between membrane proteins and the actin cytoskeleton [13]. Leukocytic adhesion molecules (selectin, LFA-1, VLA-4, ICAM-1) also interact with cytoskeletal proteins using cytoplasmic actin-binding proteins $\left(\mathrm{ABP}_{\mathrm{S}}\right.$ : actinin, paxillin, vinculin and tallinn), which activate Arp2/3 complex triggering the 
actin polymerization [9]. Arp2/3 complex is a matrix where new actin filaments are formed, in addition, the complex joins in the middle of actin filaments and promotes their branching [14]. Actin filaments in this case are formed at an angle of $70^{\circ}$ to previously formed actin filaments. Those filaments push the membrane forward from the side of their growth (from leader (growing) ends). As a result of ATP hydrolysis, the macroergic phosphate necessary for the polymerization of new actin filaments and actin filaments at the lagging end, involving ADP/kofilin complex in the lamel region, experiences depolymerization [15]. Thus the transfer of leukocytes is dynamic and multistage cascade process requiring the activation of various adhesion molecules and signalling pathways, as well as the restructuring of actin cytoskeleton [9]. Therefore, the study on mechanisms of the actin polymerization-depolymerization is essential for understanding the migratory abilities and functional activity of leukocytes under diabetes.

It has been previously stated [16] that in animal leukocytes under experimental diabetes mellitus (EDM) the total content of actin is reduced, whereas actin polymerization is intensified in the membrane skeleton filaments. Agmatine administration to animals with EDM increases both the total content of actin and the level of polymerized actin in the fraction of cytoskeletal filaments, which are caused by the depolymerization of short actin filaments of the plasma membrane skeleton. This polyamine either directly or indirectly affects the functional state of leukocytes. As an endogenous ligand for the imidazole receptors (I1 / I2), and with less affinity with $\alpha_{2}$-adrenergic receptors, $\mathrm{N}$-methyl-D-aspartate and serotonin receptors, agmatine lowers the glucose levels in plasma under DM [17-19]. The hypoglycemic mechanism of agmatine is provided throught direct insulin-like effects on peripheral organs, interaction with $\beta$-cells of the pancreatic islets leading to an increased release of insulin, and increased secretions of endorphins by adrenals owing to the activation of imidazole receptors, which cause the increased glucose uptake by the cells of the body [17, 20]. Therefore, agmatine can be used as a therapeutic agent for the treatment of DM and related metabolic disorders [21].

The aim of our study was to investigate the effects of agmatine on the redistribution of actin fractions represented by cytoskeletal actin filaments, short actin filaments of the plasma membrane skeleton and actin monomers (G-actin) in leukocytes of the control group of animals and rats with EDM. Since there are adhesion molecules and receptors on the surface of leukocytes, which by their biochemical nature are glycoconjugates with a high level of sialization and interact with cytoskeletal proteins through the membrane structures and signalling proteins, the dynamics of actin reorganization was evaluated after $0.5 \mathrm{~min}$, $1 \mathrm{~min}$ and $3 \mathrm{~min}$ of leukocyte preincubation with wheat germ lectin (WGA) under both normal and diabetic conditions. WGA lectin interacts with sialic acid residues that are present in terminal positions of N-linked glycoproteins, as well as with the residues of sialic acids and $\mathrm{N}$-acetyl- $\beta, \mathrm{D}$-glucosamine as part of O-glycans of glycoproteins and glycolipids [22]. Incubating leukocytes with WGA lectin, we have modelled in vitro the activation state of leukocytes. 


\section{Materials and Methods}

\section{Animal preparation}

The experiments were based on white outbred male rats weighing $150-180 \mathrm{~g}$. The animals had free access to food and water during their stay under standard vivarium conditions. The experiments were conducted in compliance with the General Ethical Principles for Conducting Experiments on Animals adopted at the First National Congress on Bioethics (Kyiv, 2001), which agree with the provisions of the European Convention for the Protection of Vertebrate Animals used for Experimental and Other Scientific Purposes (Strasbourg, 1985). The animals were divided into four groups: (1) control, (2) control + agmatine, (3) experimental diabetes mellitus (EDM), and (4) $\mathrm{EDM}+$ agmatine. EDM was induced by the intraperitoneal administration of $6 \mathrm{mg}$ streptozotocin (Sigma, United States) per $100 \mathrm{~g}$ of body mass, dissolved in $10 \mathrm{mM}$ citrate buffer ( $\mathrm{pH}$ 5.5). The development of diabetes was controlled by the blood glucose level determined $72 \mathrm{~h}$ after administering streptozotocin. Animals with a glucose level above $14 \mathrm{mM}$ were considered eligible for experiments. Starting from the third day from the moment of inducing diabetes, the animals from the second and fourth groups were intramuscularly administered agmatine (Sigma, United States) at a concentration of $20 \mathrm{~g} / \mathrm{kg}$ body weight for 14 days, while the animals from the first and third groups were intramuscularly administered saline solution for 14 days.

\section{Blood collection}

Blood was collected after light anesthesia with diethylether. Heparin was added beforehand to prevent coagulation (the end point heparin: whole blood dilution $=1: 100$ ).

\section{Isolation of blood leukocytes}

Leukocytes were isolated from blood by centrifugation in gradient of ficolltriombrast density $(r=1.076-1.078)$. Afterwards, the cells were washed twice in phosphate buffered saline (PBS: $(137 \mathrm{mM} \mathrm{NaCl}, 2.7 \mathrm{mM} \mathrm{KCl}$, $10 \mathrm{mM} \mathrm{Na} 2 \mathrm{HPO}_{4} \times 7 \mathrm{H}_{2} \mathrm{O}, 1.8 \mathrm{mM} \mathrm{KH} \mathrm{PO}_{4}$, $\mathrm{pH}$ 7.4)). Cell viability was controlled by trypanblue $(0.1 \% \mathrm{w} / \mathrm{v}$ solution $)$ exclusion test.

\section{Cell activation}

Cells $\left(1.5 \cdot 10^{6}\right)$ were preincubated for $0.5,1$ or $3 \mathrm{~min}$ at $37^{\circ} \mathrm{C}$ with WGA lectin (Lectinotest Laboratory, Lviv, Ukraine) in the final concentration of $32 \mathrm{mg} / \mathrm{ml}$. Then cells were washed with $\mathrm{PBS}^{+}(137 \mathrm{mM} \mathrm{NaCl}, 2.7 \mathrm{mM} \mathrm{KCl}$, $10 \mathrm{mM} \mathrm{Na}_{2} \mathrm{HPO}_{4} \times 7 \mathrm{H}_{2} \mathrm{O}, 1.8 \mathrm{mM} \mathrm{K \textrm {K } _ { 2 }} \mathrm{PO}_{4}$, $1 \mathrm{mM} \mathrm{CaCl}_{2}, 0.5 \mathrm{mM} \mathrm{MgCl}_{2} \times 6 \mathrm{H}_{2} \mathrm{O}, \mathrm{pH}$ 7.5).

\section{Fractionation of actin cytoskeleton}

Cells $\left(1.5 \cdot 10^{6}\right)$ were lysed in $250 \mathrm{ml}$ of the buffer composed of $0.5 \%$ Triton X-100, $100 \mathrm{mM} \mathrm{KCl}, 5 \mathrm{mM} \mathrm{MgCl} 2,2 \mathrm{mM}$ EGTA, $25 \mathrm{mM}$ Tris, $\mathrm{pH} 7.5$ and a protease inhibitor cocktail ("Sigma", USA) to separate cytoskeletal actin filaments from solubilized actin [23]. After $10 \mathrm{~min}\left(4{ }^{\circ} \mathrm{C}\right)$, cell lysates were centrifuged for $10 \mathrm{~min}$ at $10000 \mathrm{~g}$ (Fig. 1). The yielded pallet contained long cytoskeletal actin filaments, whereas the supernatant contained short actin filaments and actin monomers. After withdrawing $10 \mathrm{ml}$ samples of supernatant for SDS-PAGE analysis, the supernatants were subjected to high-speed centrifugation (1 h, 100000 g, Fig. 1) to separate actin monomers (supernatant) and plasma 


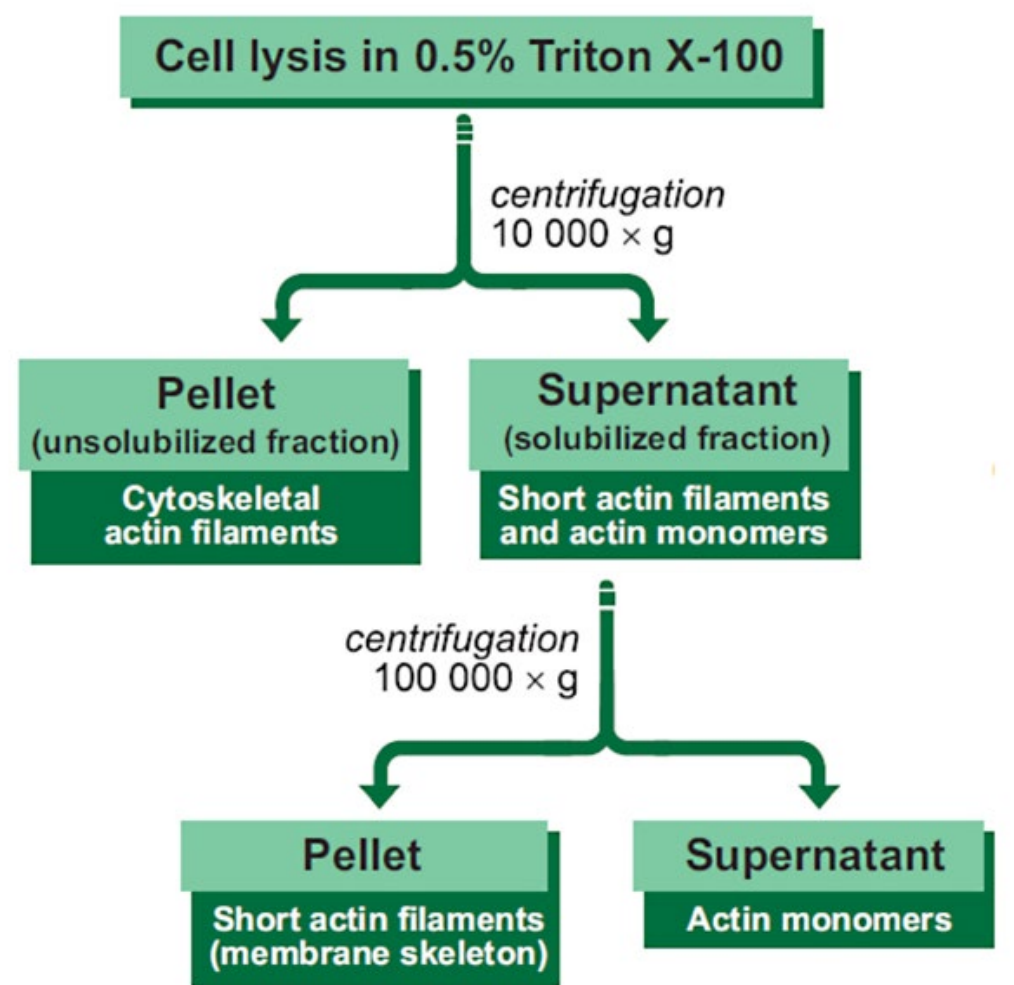

Short actin filaments

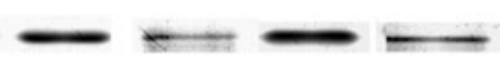

Actin monomers
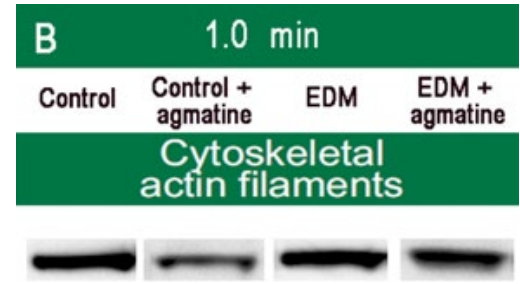

Short actin filaments

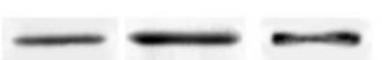

Actin monomers

Fig. 1. The immunoblot analysis of different actin fractions in leukocytes of healthy rats, rats with experimental diabetes mellitus (EDM) and after agmatine administration. The scheme for fractionating lysates obtained after cell lysis through $0.5 \%$ Triton X-100 covers the process of separation of those fractions that contain cytoskeletal actin filaments, short actin filaments of the plasma membrane skeleton and actin monomers. To determine the level of actin, we carried out the immunoblot analysis of fractions containing cytoskeletal actin filaments, short actin filaments and actin monomers: $A$ - fraction from leukocytes activated for $0.5 \mathrm{~min}$. with wheat germ lectin (WGA) and immunoblotted for actin ; $B-$ fraction from leukocytes activated for 1 min. with WGA and immunoblotted for actin; $C$ - fraction from leukocytes activated for $3 \mathrm{~min}$. with WGA and immunoblotted for actin. Equal volume of each fraction was applied onto the gel. Proteins from $1.5 \times 10^{6}$ cells were loaded per lane.

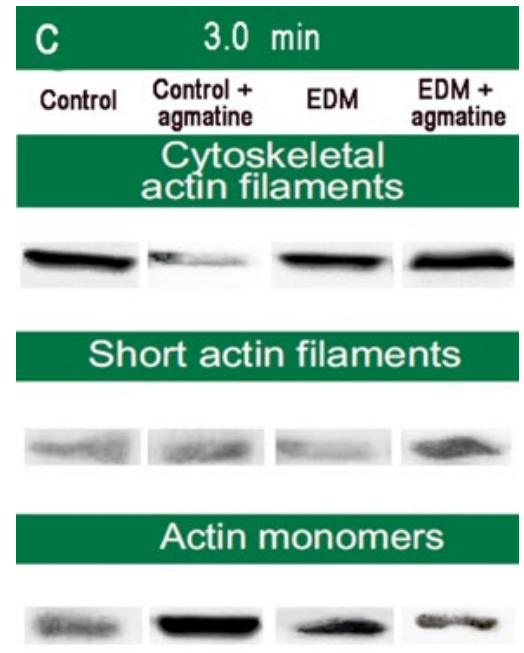

membrane skeleton (pellet). The pellet was dissolved in $30 \mathrm{ml}$ of $8 \mathrm{M}$ urea and analyzed by SDS-PAGE. To quantify actin in isolated fractions, equal volume of each fraction was applied onto a gel [23]. After immunoblotting with an anti-actin antibody, actin bands were 
analyzed densitometrically using Gelpro32. The actin content of each fraction at different time-points of WGA activation was expressed as a percentage of the total actin amount.

\section{Immunoblotting}

The lysates as well as cellular fractions were subjected to SDS-PAGE, transferred onto nitrocellulose sheets and immunoblotted essentially as described [24]. The membranes were probed with mouse IgG anti-actin antibody (MP Biomedicals, $\mathrm{OH}$ ) followed by anti-mouse IgG-peroxidase (Sheep anti-Mouse Ig Antibody, $(\mathrm{H}+\mathrm{L})$ HRP conjugate, Millipore, USA). The immunoreactive bands visualized by chemiluminescence (Pierce, IL) were analyzed densitometrically using Gelpro32.

\section{Data analysis}

The significance of differences between groups was calculated using Student's t-test. P $<0.05$ was considered to be statistically significant.

\section{Results and Discussion}

The comparative analysis of actin fraction redistribution (represented by cytoskeletal filaments, short actin filaments of the plasma membrane skeleton and actin monomers (Fig. 1A-C)) was performed on the basis of immunoblot densitometric analysis using antiactin antibodies. In the cells of the control group, those three actin forms amounted to $72 \pm 7,9 \pm 2$, and $20 \pm 3 \%$ respectively (Fig. 2).

After 0.5 min of stimulation by WGA lectin, the percentage of polymerized actin represented by cytoskeletal filaments decreased by $18 \%$, whereas the content of the short actin filament increased by $20 \%$ in leukocytes of the control group (Fig. 2). After 1 min of WGA lectin exposure, we observed exactly the opposite effect: the fraction of cytoskeletal filaments increased up to $70 \%$, whereas short actin filaments accounted for only $9 \%$ of polymerized actin. The level of actin monomers in leukocytes after 0.5 and $1 \mathrm{~min}$ exposure to lectin did not undergo any significant changes. In 3 min after WGA lectin exposure, F-actin fraction of short actin filaments of leukocytes increased from $9 \%$ to $15 \%$, which correlated with a decrease in the content of G-actin against a background of unchanged levels of cytoskeletal actin filaments. The acquired data indicate that in the control group of animals the process of actin polymerization under leukocyte activation by preincubation with WGA lectin for $0.5 \mathrm{~min}$ is intensified in the fraction of short actin filaments, and in $1 \mathrm{~min}$ - in the cytoskeletal filaments (Fig. 2). Such dynamics of actin polymerization in leukocytes of the control group apparently corresponds to the activation of those blood cells under stimulatory factors $[25,26]$.

Analyzing the redistribution of polymerized actin fractions, i.e. cytoskeletal actin filaments and short actin filaments in the initial state (Fig. 2, 0 min without WGA exposure), it was revealed that there is a decrease in the number of cytoskeletal actin filaments and an increase in short actin filaments of plasma membrane skeleton in leukocytes of diabetic animals compared with the control group in similar conditions (Fig. 2).

In $0.5 \mathrm{~min}$ of the WGA lectin stimulation, the leukocytes of diabetic animals contained $66 \pm 5 \%$ of actin in the cytoskeletal filament fraction, $25 \pm 2 \%$ in short actin filaments, and $9 \pm 1 \%$ accounted for actin monomers (Fig. 2). 
A

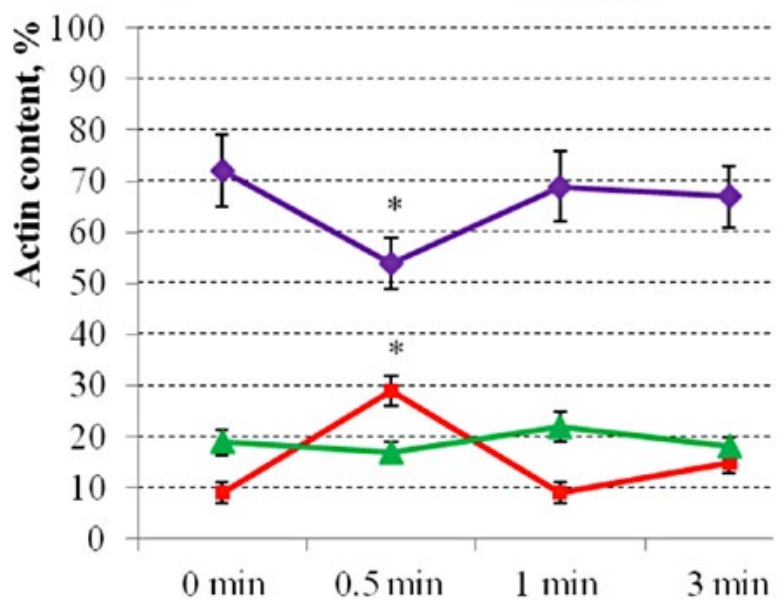

C Control + agmatine

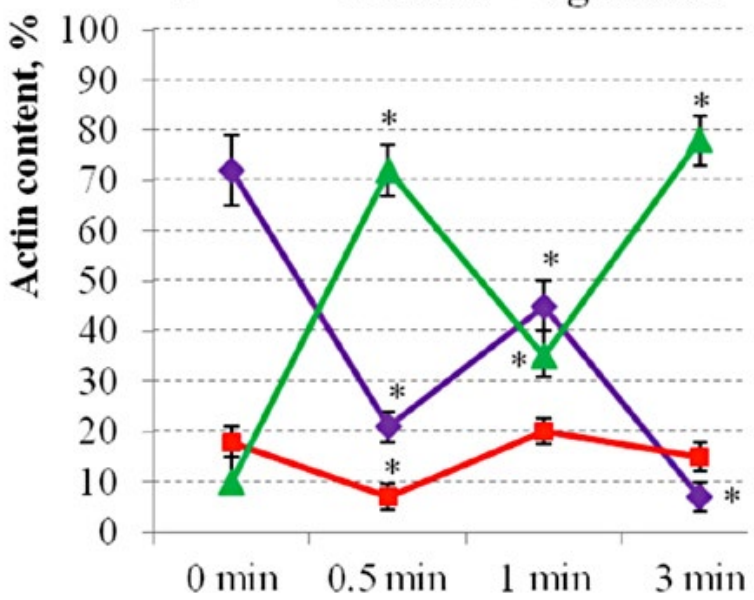

B Experimental diabetes mellitus (EDM)

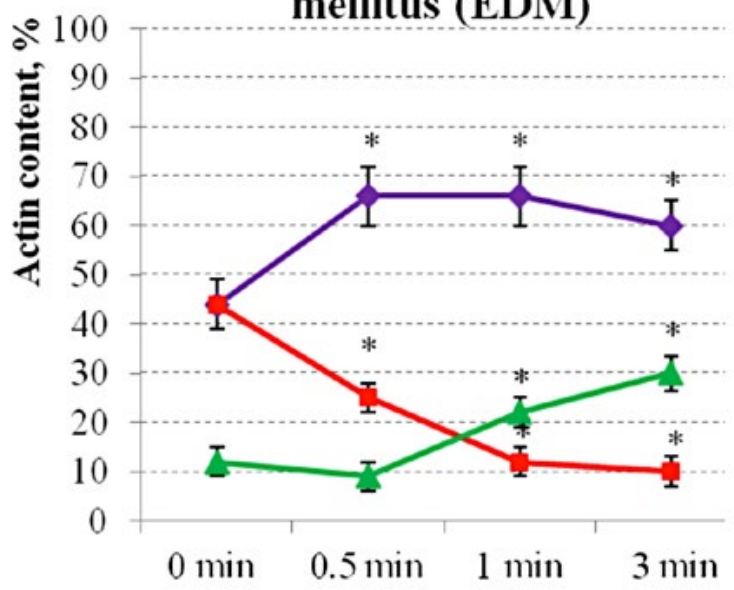

D $\quad \mathrm{EDM}+$ agmatine

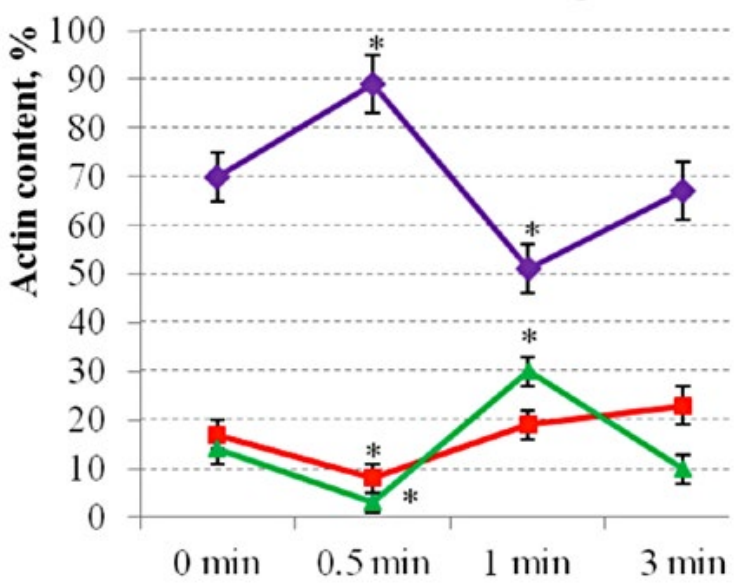

Legends: $\rightarrow$ cytoskeletal actin filaments, $\rightarrow$ shot actin filaments, $\leftarrow$ actin monomers

Fig. 2. Redistribution dynamics of actin fractions in lysates of leukocytes containing cytoskeletal actin filaments, short actin filaments and actin monomers at rest $(0 \mathrm{~min})$ and in an activation state (after preincubation with WGA lectin for thirty seconds, one minute and three minutes): $A$ - control; $B$ - experimental diabetes mellitus (EDM); $C$ - control against a background of agmatine administration; $D$ - experimental diabetes mellitus against a background of agmatine administration. The data were obtained by immunoblot densitometry (Fig. 1A-C). The actin content of each fraction at different time-points of WGA stimulation was expressed as a percentage of the total actin amount. The data are presented as the mean \pm standard mean error of five experiments: * Significantly different from unstimulated cells $(0$ min) at $\mathrm{P}<0.05$.

The obtained results indicate that under EDM the stimulation with WGA lectin leads to the intensification of actin polymerization process in the fraction of leukocyte cytoskeletal filaments due to the depolymerization of short actin filaments. The content of actin monomers 
under such conditions did not change (Fig. 2). Although the level of F-actin fraction of cytoskeletal filaments did not undergo significant changes in leukocytes under EDM after 1 and 3 min of WGA lectin exposure, the process of actin depolymerization (represented by actin of short filaments) accelerated, thus increasing the content of actin monomers up to $30 \%$ after 3 min of WGA lectin exposure (Fig. 2).

After cell activation, there is a rapid and short-term increase in F-actin, which correlates with a decrease in the content of G-actin [27]. However, under EDM the opposite processes of intensified depolymerization of short actin filaments and increased contents of G-actin take place in leukocytes activated by WGA lectin. During the activation of leukocytes, short actin filaments are involved in changing the morphology and functional capacity of the cells, whereas the reduction of their content in leukocytes under diabetes mellitus clearly causes the impairment of all those functions. Such changes may be a result of the disturbances of transmembrane and intracellular signaling through sialoglycoconjugates of leukocytes, the number and structural organization of oligosaccharide chains of which are changed under EDM [28].

The results are consistent with our earlier research [29], which revealed that under type $1 \mathrm{DM}$ the PI-3'-kinase signaling pathway, which in fact causes the delay of WGAstimulating signal transduction, in blood leukocytes is misaligned and slowed. PI-3'-kinase signaling pathway is involved in cellular response to external stimuli by regulating the activity of proteins of the cytoskeleton [14] and forming stress fibrils, lamellipodia and filopodia of leukocytes [30, 31]. Changes in the level of actin polymerization-depolymerization in leukocytes under EDM may indicate a breach in systems of activation, adhesion and phagocytosis, as well as manifestation of cytotoxicity, because the actin cytoskeleton of leukocytes is continually reorganized, being a dynamic system that determines the morphological changes in the cell $[32,33]$.

After agmatine administration, actin fractions in leukocytes were distributed as follows in the control group of rats: $72 \pm 6 \%$ in the fraction containing membrane filaments closely associated with the cytoskeleton, $18 \pm 3 \%$ represented short actin filaments, and actin monomers accounted for $10 \pm 2 \%$ (Fig. 2). Thus, the administration of agmatine to the control group of animals leads to the reduction of actin monomers due to the intensification of actin filament polymerization in the plasma membrane skeleton in comparison with unstimulated leukocytes from the control group of animals (Fig. 2).

In leukocytes of the control group of animals against the background of agmatine administration after $0.5 \mathrm{~min}$ of WGA lectin stimulation, the percentage of polymerized actin represented by cytoskeletal filaments and short actin filaments, decreased by $50 \%$ and $11 \%$ respectively. Such an intensive process of depolymerization led to a sharp increase in G-actin - from $10 \%$ in the state of inactivation to $72 \%$ in the state of leukocyte activation by WGA lectin for thirty seconds. After $1 \mathrm{~min}$ WGA lectin exposure, we observed just the opposite effect - an intensive process of actin polymerization caused an increase in F-actin filaments of the cytoskeletal fraction up to $45 \%$, whereas the fraction of short actin filaments increased up to $20 \%$. The level of actin 
monomers in leukocytes after 1 min WGA lectin exposure decreased twofold. In $3 \mathrm{~min}$ after WGA lectin exposure, the level of F-actin filaments of the leukocyte cytoskeleton dropped to $7 \%$, which correlated with an increase in G-actin content up to about $80 \%$. The obtained data indicate that in the control group of animals the agmatine administration causes the formation of leukocyte response to activation signals after $1 \mathrm{~min}$ exposure to WGA lectin, and it terminates the process of actin filament cell reorganization if the cells are preincubated for 3 min (Fig. 2). Consequently, the dynamics of actin redistribution in this group of animals shows that major changes in activated leukocytes occur in the cytoskeletal filaments, correlating with the changes in actin monomers. Since the level of F-actin fraction of short actin filaments after 1 and 3 min. of WGA lectin stimulating effects does not undergo significant changes as compared to the initial state of leukocytes ( 0 min. - without WGA exposure), it can be assumed that in the control group of animals agmatine causes the cytoskeletal actin filaments polymerization de novo at the exposure of actin monomers at 1 min of WGA lectin action, involving the activation of Arp2/3 complex [34].

If agmatine is administered to animals with EDM, the process of polymerization in leukocytes intensifies in the fraction of cytoskeletal filaments and depolymerization of short actin filaments occurs compared to animals under EDM without agmatine administration (Fig. 2, see 0 min.). Under EDM, against a background of agmatine administration, the stimulating effect of WGA lectin exposure for $0.5 \mathrm{~min}$. leads to the intensification of actin polymerization process in the cytoskeletal filament frac- tion of leukocytes due to depolymerization of short actin filaments and usage of actin monomers (Fig. 2). After 1 min WGA lectin exposure, the level of F-actin filaments of the leukocyte cytoskeleton reduced by $40 \%$, which correlated with an increase in G-actin content up to $30 \%$ and short actin filaments up to $20 \%$ (Fig. 2). After 3 min of WGA lectin stimulation in leukocytes of animals with EDM against the background of agmatine administration, actin was redistributed among the three fractions in the following ratio $-67 \pm 8,23 \pm 3$ and $10 \pm 1$, reaching the level of performance in an inactive state (Fig. 2, see 0 and $3 \mathrm{~min}$.).

Therefore, in leukocytes of animals with EDM, against the background of agmatine administration, the dynamics of response to stimulating effects of WGA lectin were characterized by the intensification of polymerization of cytoskeletal actin filaments already after 0.5 min exposure to lectin, by exceptionally rapid depolymerization processes after $1 \mathrm{~min}$ exposure to lectin, and by the return to the performance level in the initial state after 3 min exposure to lectin (Fig. 2). Under those conditions, the WGA lectin binds to complementary glycoconjugates on the surface of leukocytes and lectin-induced signal transduction, which causes the reorganization of the actin cytoskeleton, reach actin content in each fraction similarly to the activated leukocytes of the control group of animals. The findings indicate that agmatine positively affects the functional state of the animal leukocytes under EDM. Perhaps the normalization of glucose level in animals with EDM in response to agmatine $[35,36]$ is one of the mechanisms for mediating those functional changes in leukocytes under EDM. 


\section{Conclusions}

Based on our previous results $[22,28]$ and obtained data, we can conclude that under EDM the changes in the number and structural organization of sialoglycoconjugates on the surface of leukocytes lead to the disruption of WGA-induced transmembrane and intracellular signaling, resulting in the enhanced depolymerization processes of short actin filaments and an increase in the content of G-actin.

In leukocytes of the animals with EDM, against the background of agmatine administration, the transduction of lectin-induced signal through sialoglycoconjugates causes a quantitative redistribution of actin fractions. It indicates that polyamine helps to restore and maintain the functional response of leukocytes to the activation signals.

\section{REFERENCES}

1. Alba-Loureiro TC, Munhoz CD, Martins JO, Cerchiaro GA, Scavone C, Curi R, Sannomiya P. Neutrophil function and metabolism in individuals with diabetes mellitus. Braz J Med Biol Res. 2007; 40(8):1037-44.

2. McManus LM, Bloodworth RC, Prihoda TJ, Blodgett JL, Pinckard RN. Agonist-dependent failure of neutrophil function in diabetes correlates with extent of hyperglycemia. J Leukoc Biol. 2001;70(3): 395-404.

3. Tipu HN, Ahmed TA, Bashir MM. Human leukocyte antigen class II susceptibility conferring alleles among non-insulin dependent diabetes mellitus patients. J Coll Physicians Surg Pak. 2011;21(1):26-9.

4. Vicente-Manzanares M, Sánchez-Madrid F. Role of the cytoskeleton during leukocyte responses. Nat Rev Immunol. 2004;4(2):110-22.

5. Ley K, Laudanna C, Cybulsky MI, Nourshargh S. Getting to the site of inflammation: the leukocyte adhesion cascade updated. Nat Rev Immunol. 2007;7(9):678-89.
6. Galbraith CG, Yamada KM, Galbraith JA. Polymerizing actin fibers position integrins primed to probe for adhesion sites. Science. 2007;315(5814):992-5.

7. Narita A, Mueller J, Urban E, Vinzenz M, Small JV, Maéda $Y$. Direct determination of actin polarity in the cell. J Mol Biol. 2012;419(5):359-68.

8. Arjonen A, Kaukonen R, Ivaska J. Filopodia and adhesion in cancer cell motility. Cell Adh Migr. 2011;5(5):421-30.

9. Schnoor M. Endothelial actin-binding proteins and actin dynamics in leukocyte transendothelial migration. $J$ Immunol. 2015;194(8):3535-41.

10. Rullo J, Becker H, Hyduk SJ, Wong JC, Digby G, Arora PD, Cano AP, Hartwig J, McCulloch CA, Cybulsky MI. Actin polymerization stabilizes $\alpha 4 \beta 1$ integrin anchors that mediate monocyte adhesion. J Cell Biol. 2012;197(1):115-29.

11. Fukuyama T, Ogita H, Kawakatsu T, Inagaki M, Takai Y. Activation of Rac by cadherin through the c-Src-Rap1-phosphatidylinositol 3-kinase-Vav2 pathway. Oncogene. 2006;25(1):8-19.

12. Heit B, Liu L, Colarusso P, Puri KD, Kubes P. PI3K accelerates, but is not required for, neutrophil chemotaxis to fMLP. J Cell Sci. 2008;121(Pt 2):205-14.

13. Snapp KR, Heitzig CE, Kansas GS. Attachment of the PSGL-1 cytoplasmic domain to the actin cytoskeleton is essential for leukocyte rolling on P-selectin. Blood. 2002;99(12):4494-502.

14. Welch $M D$. The world according to Arp: regulation of actin nucleation by the Arp2/3 complex. Trends Cell Biol. 1999;9(11):423-7.

15. Pollard TD, Blanchoin L, Mullins RD. Molecular mechanisms controlling actin filament dynamics in nonmuscle cells. Annu Rev Biophys Biomol Struct. 2000;29:545-76.

16. Brodyak IV, Bila II, Overchuk M, Sybirna NO. Effect of agmatine on actin polymerization in leukocytes of strep-tozotocin-induced diabetic rats. Studia Biologica. 2014; 8(3-4):17-30.

17. Chang $\mathrm{CH}$, Wu HT, Cheng KC, Lin HJ, Cheng JT. Increase of beta-endorphin secretion by agmatine is induced by activation of imidazoline I $(2 \mathrm{~A})$ receptors in adrenal gland of rats. Neurosci Lett. 2010;468(3):297-9.

18. Hwang SL, Liu IM, Tzeng TF, Cheng JT. Activation of imidazoline receptors in adrenal gland to lower 
plasma glucose in streptozotocin-induced diabetic rats. Diabetologia. 2005;48(4):767-75.

19. Jou SB, Liu IM, Cheng JT. Activation of imidazoline receptor by agmatine to lower plasma glucose in streptozotocin-induced diabetic rats. Neurosci Lett. 2004;358(2):111-4.

20. Lee JP, Chen W, Wu HT, Lin KC, Cheng JT. Metformin can activate imidazoline I-2 receptors to lower plasma glucose in type 1-like diabetic rats. Horm Metab Res. 2011;43(1):26-30.

21. Piletz JE, Aricioglu F, Cheng JT, Fairbanks CA, Gilad VH, Haenisch B, Halaris A, Hong S, Lee JE, Li J, Liu P, Molderings GJ, Rodrigues AL, Satriano J, Seong GJ, Wilcox G, Wu N, Gilad GM. Agmatine: clinical applications after 100 years in translation. Drug Discov Today. 2013;18(17-18):880-93.

22. Sybirna NO, Shevtsova AI, Ushakova GO, Brodyak IV, Pismenetzka IY. Fundamentals of glycobiology. Monograph; Lviv: Ivan Franko National University of Lviv, 2015. 492 p.

23. Kleveta $G$, Borzęcka K, Zdioruk M, Czerkies $M$, Kuberczyk H, Sybirna N, Sobota A, Kwiatkowska K. LPS induces phosphorylation of actin-regulatory proteins leading to actin reassembly and macrophage motility. J Cell Biochem. 2012;113(1):80-92.

24. Kwiatkowska K, Frey J, Sobota A. Phosphorylation of FcgammaRIIA is required for the receptor-induced actin rearrangement and capping: the role of membrane rafts. $J$ Cell Sci. 2003;116(Pt 3):537-50.

25. Fenteany $G$, Zhu S. Small-molecule inhibitors of actin dynamics and cell motility. Curr Top Med Chem. 2003;3(6):593-616.

26. Lin BH, Tsai MH, Lii CK, Wang TS. IP3 and calcium signaling involved in the reorganization of the actin cytoskeleton and cell rounding induced by cigarette smoke extract in human endothelial cells. Environ Toxicol. 2016;31(11):1293-1306.

27. Watts $R G$, Crispens MA, Howard TH. A quantitative study of the role of F-actin in producing neutrophil shape. Cell Motil Cytoskeleton. 1991;19(3):159-68.

28. Ferents I, Brodyak I, Lyuta M, Klymyshyn N, Burda V, Sybirna N. Sialylation status of leukocyte cell-surface glycoconjugates in streptozotocin-induced diabetic rats and after treatment with agmatine. Curr Iss Pharm Med Sci. 2013; 26(4):390-2.
29. Sybirna NO, Zdioruk MI, Brodiak IV, Bars'ka ML, Vovk OI. [Activation of the phosphatidylinositol-3'kinase pathway with lectin-induced signal through sialo-containing glycoproteins of leukocyte membranes under type 1 diabetes mellitus]. Ukr Biokhim Zh. (1999). 2011;83(5):22-31.

30. Aiba Y, Kameyama M, Yamazaki T, Tedder TF, Kurosaki T. Regulation of B-cell development by BCAP and CD19 through their binding to phosphoinositide 3-kinase. Blood. 2008;111(3):1497-503.

31. Fais $S$, Malorni $W$. Leukocyte uropod formation and membrane/cytoskeleton linkage in immune interactions. J Leukoc Biol. 2003;73(5):556-63.

32. Pollard TD, Borisy GG. Cellular motility driven by assembly and disassembly of actin filaments. Cell. 2003;112(4):453-65. Review. Erratum in: Cell. 2003;113(4):549.

33. Zarbock A, Kempf T, Wollert KC, Vestweber D. Leukocyte integrin activation and deactivation: novel mechanisms of balancing inflammation. $J \mathrm{Mol}$ Med (Berl). 2012;90(4):353-9.

34. Samstag Y, Eibert SM, Klemke M, Wabnitz GH. Actin cytoskeletal dynamics in T lymphocyte activation and migration. J Leukoc Biol. 2003;73(1):30-48.

35. Ferents IV, Brodyak IV, Lyuta MYa, Sybirna NO. Effect of agmatine on the blood system parameters of rats un-der the condition of experimental diabetes mellitus. Studia Biologica. 2012; 6(3):65-72.

36. Wu G, Bazer FW, Davis TA, Kim SW, Li P, Marc Rhoads J, Carey Satterfield M, Smith SB, Spencer TE, Yin Y. Arginine metabolism and nutrition in growth, health and disease. Amino Acids. 2009; 37(1):153-68.

\section{Динаміка полімеризації актинових філаментів в активованих лейкоцитах за умов експериментального цукрового діабету на фоні введення агматину}

\section{I. В. Бродяк, І. І. Біла, Н. О. Сибірна}

Мета. Дослідити вплив агматину на перерозподіл фракцій актину, які представлені актиновими філаментами цитоскелету, короткими актиновими філаментами скелету плазматичної мембрани і мономерами актину (G-актин), у лейкоцитах щурів з експерименталь- 
ним цукровим діабетом (ЕЦД) Методи. Лейкоцити лізували в Тритоні X-100 і піддавали центрифугуванню, у результаті якого було отримано актинові філаменти цитоскелету, короткі актинові філаменти і мономери актину, які розділяли в SDS-ПААГ, після чого проводили імуноблот аналіз із використанням антиактинових антитіл. Результати. За умов ЕЦД у лейкоцитах, активованих сіалоспецифічним лектином зародків пшениці (WGA), спостерігається інтенсифікування процесу деполімеризації коротких актинових філаментів і збільшення вмісту G-актину, а на фоні введення агматину динаміка формування відповіді на WGA-стимулювальний вплив характеризувалася посиленням полімеризації актину у фракції філаментів цитоскелету вже на 0,5 хв впливу лектину, дуже стрімким процесом деполімеризації на 1 хв після дії лектину та поверненням показників до рівня у вихідному стані у разі дії лектину впродовж 3 хв. Висновки. У лейкоцитах тварин з ЕЦД на фоні введення агматину трансдукція WGA-індукованого сигналу через сіалоглікокон'югати зумовлює перерозподіл вмісту актину, вказуючи на те, що даний поліамін сприяє відновленню і підтриманню функціональної відповіді лейкоцитів на активаційні сигнали.

К л ю ч о в і с л о в а: актин, лейкоцити, агматин, експериментальний цукровий діабет.

\section{Динамика полимеризации актиновых филаментов в активированных лейкоцитах в условиях экспериментального сахарного диабета на фоне введения агматина}

И. В. Бродяк, И. И. Била, Н. А. Сибирна

Цель. Исследовать влияние агматина на перераспределение фракций актина, которые представлены актиновыми филаментами цитоскелета, короткими актиновыми филаментами скелета плазматической мембраны и мономерами актина (G-актин), в лейкоцитах крыс с экспериментальным сахарным диабетом (ЭСД). Методы. Лейкоциты лизировали в Тритоне X-100 и подвергали центрифугированию, в результате которого было получено актиновые филаменты цитоскелета, короткие актиновые филаменты и мономеры актина, которые разделяли в SDS-ПААГ, после чего проводили иммуноблот анализ с использованием антиактиновых антител. Результаты. В условиях ЭСД в лейкоцитах, активированных сиалоспецыфическим лектином зародышей пшеницы (WGA), наблюдается интенсификация процесса деполимеризации коротких актиновых филаментов и увеличение содержания G-актина, а на фоне введения агматина динамика формирования ответа на WGA-стимулирующее влияние характеризировалась усилением полимеризации актина во фракции филаментов цитоскелета уже на 0,5 мин влияния лектина, очень стремительным процессом деполимеризации на 1 мин после действия лектина и возвращением показателей к уровню в исходном состоянии в случае действия лектина в течение 3 мин. Выводы. В лейкоцитах животных с ЭСД на фоне введения агматина трансдукция WGA-индуцированого сигнала через сиалогликоконьюгаты приводит к перераспределению содержания актина, указывая на то, что данный полиамин способствует восстановлению и поддержанию функционального ответа лейкоцитов на активационные сигналы.

К л юч е в ы е с л о в а: актин, лейкоциты, агматин, экспериментальный сахарный диабет.

Received 20.09.2017 